\title{
Tetramethylbenzidine: An Acoustogenic Photoacoustic Probe for Reactive Oxygen Species Detection
}

\author{
Roger Bresolí-Obach ${ }^{1,2}{ }^{(0)}$, Marcello Frattini ${ }^{1,3}{ }^{\text {, Stefania Abbruzzetti }}{ }^{3}{ }^{(0)}$, Cristiano Viappiani ${ }^{3}$, \\ Montserrat Agut ${ }^{1}$ (D) and Santi Nonell ${ }^{1, *(D)}$ \\ 1 Institut Químic de Sarrià, Universitat Ramon Llull, Via Augusta 390, 08017 Barcelona, Spain; \\ roger.bresoliobach@kuleuven.be (R.B.-O.); marcello.frattini7@gmail.com (M.F.); \\ montserrat.agut@iqs.url.edu (M.A.) \\ 2 Department of Chemistry, Katholieke Universiteit Leuven, celestijnenlaan 200F, \\ 3001 Heverlee (Leuven), Belgium \\ 3 Dipartimento di Scienze Matematiche, Fisiche e Informatiche, Università di Parma, Parco Area delle Scienze \\ 7A, 43124 Parma, Italy; stefania.abbruzzetti@unipr.it (S.A.); cristiano.viappiani@unipr.it (C.V.) \\ * Correspondence: santi.nonell@iqs.url.edu; Tel.: +34-93-267-2000
}

Received: 22 September 2020; Accepted: 18 October 2020; Published: 21 October 2020

\begin{abstract}
Photoacoustic imaging is attracting a great deal of interest owing to its distinct advantages over other imaging techniques such as fluorescence or magnetic resonance image. The availability of photoacoustic probes for reactive oxygen and nitrogen species (ROS/RNS) could shed light on a plethora of biological processes mediated by these key intermediates. Tetramethylbenzidine (TMB) is a non-toxic and non-mutagenic colorless dye that develops a distinctive blue color upon oxidation. In this work, we have investigated the potential of TMB as an acoustogenic photoacoustic probe for ROS/RNS. Our results indicate that TMB reacts with hypochlorite, hydrogen peroxide, singlet oxygen, and nitrogen dioxide to produce the blue oxidation product, while ROS, such as the superoxide radical anion, sodium peroxide, hydroxyl radical, or peroxynitrite, yield a colorless oxidation product. TMB does not penetrate the Escherichia coli cytoplasm but is capable of detecting singlet oxygen generated in its outer membrane.
\end{abstract}

Keywords: 3,3',5,5' -tetramethylbenzidine; reactive oxygen species (ROS); reactive nitrogen species (RNS); photoacoustic probes; optical sensors; singlet oxygen

\section{Introduction}

Reactive oxygen species (ROS) are a family of oxygen-based molecules including singlet oxygen $\left({ }^{1} \mathrm{O}_{2}\right)$, superoxide radical anion $\left(\mathrm{O}_{2}^{\bullet-}\right)$, hydrogen peroxide $\left(\mathrm{H}_{2} \mathrm{O}_{2}\right)$, hydroxyl radical $\left({ }^{\bullet} \mathrm{OH}\right)$, and peroxyl radical $\left(\mathrm{ROO}^{\bullet}\right)$, as well as hypochlorous acid and hypochlorite anion ( $\mathrm{HClO}$ and $\mathrm{ClO}^{-}$, respectively) [1]. In low concentrations, ROS are adventitiously produced in several metabolic processes of aerobic organisms [2], derived from molecular ground oxygen $\left({ }^{3} \mathrm{O}_{2}\right)$, and show high reactivity mainly as oxidant species. ROS oxidant effects are usually controlled by the cell's antioxidant defense mechanism [3]. However, when such processes are insufficient or overwhelmed, an accumulation of free ROS takes place inside cells, which are readily reactive towards proteins, nucleic acids, and/or lipids [4]. Elevated ROS concentrations can lead to irreversible damage and eventually to cell death. In addition to ROS, reactive nitrogen species (RNS) present also a high oxidative reactivity towards biomolecules. RNS are a family of molecules derived from nitric oxide $\left({ }^{\bullet} \mathrm{NO}\right)$, such as nitrogen dioxide $\left({ }^{\bullet} \mathrm{NO}_{2}\right)$, nitrite $\left(\mathrm{NO}_{2}{ }^{-}\right)$, or peroxynitrite $\left(\mathrm{ONOO}^{-}\right)$[5]. RNS can act alone or together with ROS to damage cells, mainly exerting nitrosative stress [6]. ROS and RNS can also be generated by light, whereby a photoexcited 
molecule can initiate a cascade of energy- or electron-transfer processes leading to the formation of ROS/RNS [7]. Medical technologies, such as photodynamic therapy, take advantage of this effect to locally eliminate cancerous cells or pathogenic microorganisms [8,9].

Due to their important role in biological and medical processes, ROS/RNS detection techniques are required to monitor and quantify them with spatio-temporal resolution [10]. Currently available techniques can be broadly classified into two groups, one in which the analyte is directly monitored, e.g., ${ }^{1} \mathrm{O}_{2}$ through its near-infrared phosphorescence, or $\mathrm{O}_{2}{ }^{\bullet-}$ through electronic paramagnetic resonance [11,12], or when the analyte reacts with some chemical probe which is then detected by suitable analytical techniques [13]. Direct techniques, while providing the advantage of specificity, lack in most cases the required sensitivity and require costly specialized equipment, which makes the indirect approach more convenient and widespread, especially when conventional techniques, such as absorption or fluorescence spectroscopy, are used [14,15]. Several selective fluorescent probes for the detection of the most important ROS/RNS have been extensively developed and their use has been protocolized [16]. However, these optical techniques also present severe drawbacks when applied to biological systems, let alone living organisms, the main one is the poor penetration of light, e.g., in human tissue, and the strong scattering that prevent the detection of light emitted or reflected by deep targets [17]. These limitations can be circumvented using photoacoustic techniques, which provide deep tissue penetration [18,19]. For example, different internal organs such as the liver, lung, or brain have been imaged in vivo using photoacoustic techniques.

The photoacoustic phenomenon was discovered by A.G. Bell, more than one century ago [20]. Briefly, when a molecule absorbs radiant energy, an excited state is created that eventually releases the acquired extra energy by a combination of radiative and non-radiative decay processes. In some cases, it may undergo also a photochemical reaction. Non-radiative decay processes cause a local heating of the molecules' microenvironment and hence its thermal expansion, leading to a pressure wave that propagates through the medium. This pressure wave can be detected by an ultrasonic microphone (e.g., a piezoelectric detector). The intensity of the photoacoustic signal is proportional to the light-induced pressure change, i.e., to the amount of heat released. Additionally, light-induced molecular rearrangements can also result in volume changes and may also contribute to the photoacoustic signal. The main advantage of detecting ultrasound waves in comparison with visible light is that their propagation is less affected by absorption and/or cell scattering processes (or the tissue in vivo) [21,22].

Photoacoustic imaging relies on the use of photoacoustic probes, substances that, after interaction with an analyte, change their ability to induce a pressure wave upon exposure to light. An ideal photoacoustic probe should fulfill a series of requirements: i) it should have a high molar absorption coefficient, ii) it should release all the absorbed energy as heat as fast as possible, and iii) it should have high photobleaching resistance [23]. As photoacoustic probes are comparatively less developed than fluorescent probes, early works on biological photoacoustic imaging used the available fluorescent probes [24-28]. In 2014, the first ROS photoacoustic nanosensor was developed by embedding a cyanine 7 derivative to a semiconductive polymeric nanoparticle [29]. Since then, a few more examples of photoacoustic nanosensors have been developed for ROS/RNS detection (e.g., a photoactivatable, reversible or theranostic photoacoustic nanosensor among others) [30-32].

The use of fluorescent probes for photoacoustic imaging seems far from efficient because fluorescent dyes will waste a fraction of their excited-state energy by emitting a photon. Hatamimoslehabadi et al. have compared the photophysical properties with the photoacoustic response for a selection of established chromophores, revealing the importance of a large non-radiative/radiative decay rate constant ratio for a good photoacoustic performance [33]. For example, fluorescein is a highly emissive dye with poor photoacoustic properties, while phenolphthalein, a fluorescein derivative, is non-fluorescent yet shows good photoacoustic properties [34]. Weakly fluorescent dyes or intrinsic fluorescent nanomaterials (e.g., nanodiamonds) have been developed and used as dual (fluorescence and photoacoustic) imaging agents $[35,36]$. Thus, fluorescent dyes with small fluorescent quantum 
yield have been used for photoacoustic imaging in the red or near-infrared regions [37]. More complex strategies such as fluorophore aggregation or non-linear absorption processes have also been used to boost the photoacoustic signal [38,39].

Recently, a simple approach has been proposed that boosts the responsivity of photoacoustic probes, namely, the use of acoustogenic dyes that change color upon reaction with the analyte of choice [40]. The acoustogenic dye is photoacoustically silent in its native form and produces a photoacoustic signal after interaction with the analyte, offering, in principle, infinite contrast. We performed a bibliographic search to identify potential acoustogenic dyes highly reactive against ROS/RNS. A non-colored, non-toxic, and non-carcinogenic compound that reacts with some ROS generating a blue oxidized complex is 3,3',5,5'-tetramethylbenzidine (TMB) [41-43]. TMB is currently used as a visualizing reagent in ELISA assays, taking advantage of its oxidation with $\mathrm{H}_{2} \mathrm{O}_{2}$ in the presence of horseradish peroxidase [44].

As shown in Scheme 1, TMB reacts with an oxidant agent to yield a radical cation $\left(\mathrm{TMB}^{\bullet+}\right)$, which forms a blue $\left(\lambda_{\mathrm{abs}}=652 \mathrm{~nm}\right)$ charge transfer complex (2) with a second TMB molecule. In some cases, the presence of an additional oxidizing agent leads to a diimine product (3), which has a yellow coloration $\left(\lambda_{\mathrm{abs}}=450 \mathrm{~nm}\right)[41,43,45]$. Finally, with a large excess of an oxidizing agent, the reaction will proceed to yield other non-colored oxidized derivatives. In this work, we have assessed the potential of TMB as an acoustogenic photoacoustic probe for ROS/RNS using laser-induced optoacoustic spectroscopy (LIOAS). We have studied its reactivity towards different ROS/RNS in water and have used it to detect ${ }^{1} \mathrm{O}_{2}$ generated in E. coli cells.

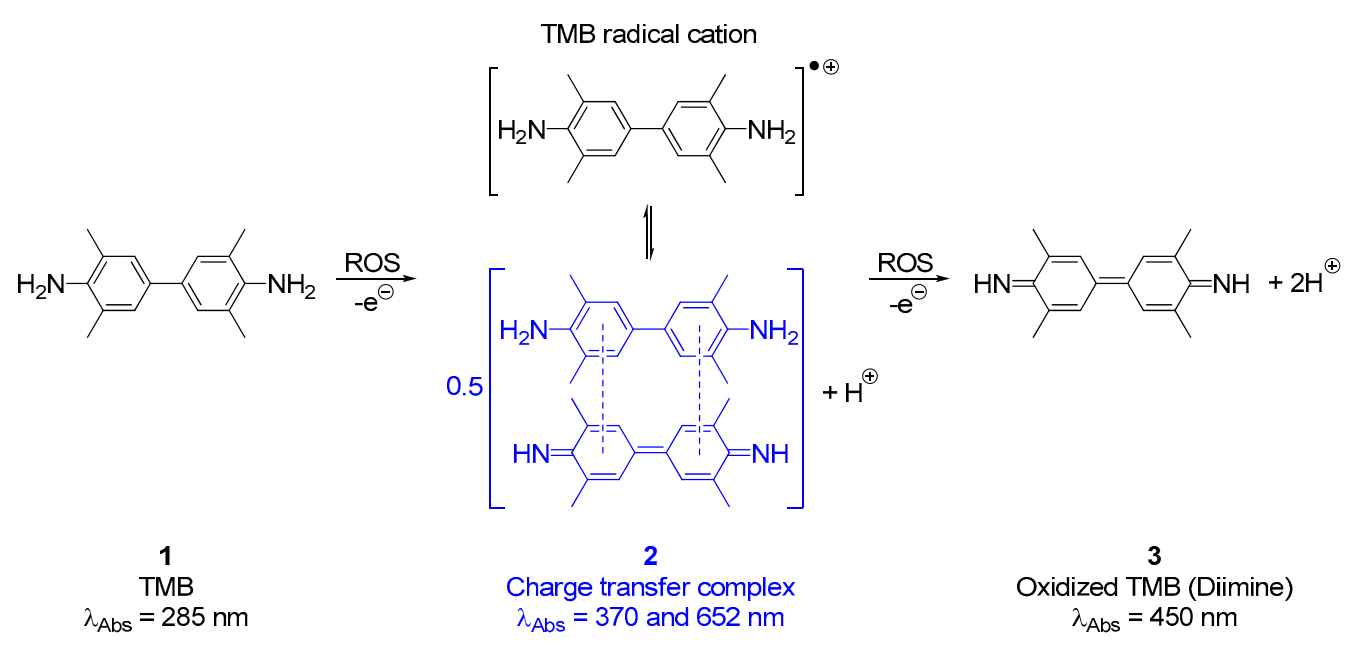

Scheme 1. TMB $\left(3,3^{\prime}, 5,5^{\prime}\right.$-tetramethylbenzidine) reactivity towards oxidant agents.

\section{Materials and Methods}

\subsection{Materials}

$\operatorname{TMB}\left(3,3^{\prime}, 5,5^{\prime}\right.$-tetramethylbenzidine), sodium hypochlorite solution (50 g/l in $\left.\mathrm{H}_{2} \mathrm{O} ; \mathrm{NaClO}\right)$, potassium superoxide $\left(\mathrm{KO}_{2}\right)$, Rose Bengal (RB), 2,2,6,6-tetramethylpiperidin-1-yl)oxyl (TEMPO), sodium azide $\left(\mathrm{NaN}_{3}\right)$, bromocresol purple $(\mathrm{BCP})$ and phosphate-buffered saline (PBS; $\mathrm{pH}=7.4$ ) were purchased from Sigma-Aldrich (St. Louis, MO, USA). Hydrogen peroxide solution (30 wt \% in $\left.\mathrm{H}_{2} \mathrm{O} ; \mathrm{H}_{2} \mathrm{O}_{2}\right)$, sodium nitrite $\left(\mathrm{NaNO}_{2}\right)$, sodium nitroprusside $\left(\mathrm{Na}_{2}\left[\mathrm{Fe}(\mathrm{CN})_{5} \mathrm{NO}\right]\right)$, and Luria-Bertani (LB) medium were supplied by Panreac (Barcelona, Spain). MDPyTMPyP (5-mono(N-decyl-4-pyridyl)-10,15,20-tri(N-methyl-4-pyridyl)-21H,23H-porphine tetrachloride) was supplied by Frontier Scientific (Logan, UT, USA). All reagents were used as received. 


\subsection{General Spectroscopic Measurements}

All spectroscopic measurements were carried out in 1-cm quartz cuvettes (Hellma, Germany) at room temperature. Absorption spectra were recorded on a Cary 6000i spectrophotometer (Varian, Palo Alto, CA, USA).

The time-resolved photoacoustic signals were recorded using home-built LIOAS equipment. TMB was excited using a Q-switched Nd:YAG laser (Surelite I-10, Continuum, CA, USA) coupled to an optical parametric oscillator (OPO) laser (SL OPO, $5 \mathrm{~ns}$ pulse width, 10-100 $\mu \mathrm{J}$ per pulse, Continuum, CA, USA). The excitation wavelengths were $652 \mathrm{~nm}$ or $450 \mathrm{~nm}$ depending on the experiment. The laser power was varied using neutral density filters. The laser beam was passed through a vertical slit of dimensions $5 \times 1 \mathrm{~mm}$ immediately before entering the cuvette. Then, the laser-induced pressure changes in the sample were detected by a Panametrics piezoelectric transducer pressed to the sidewall of a cuvette and held in a temperature-controlled holder (Quantum Northwest, WA, USA). A thin layer of silicon grease (Baysilone-35, Bayer, Leverkusen, Germany) ensured optimum acoustic coupling between the cuvette and the piezoelectric transducer. After amplification, the signal was fed to a Lecroy Wavesurfer 454 oscilloscope (Teledyne LeCroy, VA, USA) for digitizing and averaging (typically 1000 shots) and finally transferred to a PC for data storage and analysis. The amplitude of photoacoustic signal maximum $\left(H_{\max }\right)$ is proportional to the absorbed laser energy, and therefore to the energy of the laser pulse $(E)$ and the sample absorption factor by (1).

$$
H_{\text {max }}=k^{\prime} \varnothing\left[1-10^{-A}\right]
$$

where $k^{\prime}$ is a proportional constant that accounts for electronic and geometric factors of the experimental system and $\phi$ is the photoacoustic efficiency [46]. In optically thin samples, the absorption factor is proportional to the concentration of the absorber (c), which can be taken advantage of for absorber quantification purposes. Thus, Equation (1) can be simplified to Equation (2):

$$
H_{\max } \sim k^{\prime \prime} \varnothing c
$$

The $\phi$ value is determined by comparing $H_{\max }$ for optically matched solutions of the sample and a suitable photoacoustic reference (BCP dissolved in $0.1 \mathrm{M} \mathrm{NaOH}$, with $\phi=1$, was used in this work [47]) as indicated in Equation (3).

$$
\varnothing_{\text {Sample }}=\frac{H_{\text {max; Sample }}}{H_{\text {max; Ref }}} \varnothing_{\text {Ref }}
$$

\subsection{Statistical Analysis}

The limit of detection (LOD) and the limit of quantification (LOQ) were calculated as 3- and 10-fold the standard deviation of the blank interpolated to the analyte calibration curve. The standard deviation of the blank was obtained from ten independent blank samples.

\subsection{Sources of the ROS and RNS Tested}

The different ROS and RNS used in this work were prepared according to the protocols below. Sodium hypochlorite $(\mathrm{NaOCl})$ was diluted from the commercial source $(50 \mathrm{~g} / \mathrm{L}$ of $\mathrm{NaClO}$ in water). Superoxide anion radical $\left(\mathrm{O}_{2}{ }^{-}\right)$was added as solid $\mathrm{KO}_{2}$. Hydrogen peroxide $\left(\mathrm{H}_{2} \mathrm{O}_{2}\right)$ was diluted from the commercial source $\left(\mathrm{H}_{2} \mathrm{O}_{2} 30 \%\right.$ in water). Hydroxyl radical $\left({ }^{\circ} \mathrm{OH}\right)$ was generated by irradiation of $10 \mathrm{mM} \mathrm{NaNO}_{2}$ solution with UV-A light $\left(354 \pm 20 \mathrm{~nm}\right.$ ) [48]. The generation of ${ }^{\bullet} \mathrm{OH}$ was verified by scavenging it with terephthalic acid and mannitol (Figure S1; Schemes S1 and S2) [49]. Singlet oxygen $\left({ }^{1} \mathrm{O}_{2}\right)$ was generated by irradiation of Rose Bengal (a well-known ${ }^{1} \mathrm{O}_{2}$ photosensitizer) [50] with green light $(520 \pm 18 \mathrm{~nm})$. Nitric oxide $\left({ }^{\bullet} \mathrm{NO}\right)$ was generated from the thermal decomposition of an aqueous solution of $1 \mathrm{M}$ sodium nitroprusside $\left(\mathrm{Na}_{2}\left[\mathrm{Fe}(\mathrm{CN})_{5} \mathrm{NO}\right]\right)$ [51]. Peroxynitrite anion $\left(\mathrm{ONOO}^{-}\right)$was 
generated as described in [52]. Briefly, $1.5 \mathrm{M} \mathrm{NaOH}$ (aq) was added to a mixture of $0.6 \mathrm{M} \mathrm{NaNO}_{2}, 0.7$ $\mathrm{M} \mathrm{H}_{2} \mathrm{O}_{2}$, and $0.6 \mathrm{M} \mathrm{HCl}$. The $\mathrm{ONOO}^{-}$solution was used immediately after its preparation. Nitrogen dioxide $\left({ }^{\bullet} \mathrm{NO}_{2}\right)$ was generated from the decomposition of sodium nitrite $\left(\mathrm{NaNO}_{2}\right)$ [53]. Briefly, $1 \mathrm{M}$ $\mathrm{NaNO}_{2}$ solution was added to $\mathrm{H}_{2} \mathrm{SO}_{4}(96 \%)$ and the generated brownish gas was collected in a balloon and injected into a sealed cuvette containing the TMB solution. Nitrite $\left(\mathrm{NO}_{2}{ }^{-}\right)$was diluted from a $1 \mathrm{M}$ sodium nitrite solution. Then, 2,2,6,6-tetramethylpiperidin-1-yl)oxyl (TEMPO) was added as solid.

\subsection{Bacterial Cell Cultures}

\subsubsection{Escherichia coli Cells with the Endogenous PS MiniSOGs}

E. coli cells (DH10 $\beta$, Invitrogen, CA, USA) were transformed with the expression vector encoding the fluorescent proteins miniSOG wt, miniSOG Q103L, and miniSOG Q103V. Cells were grown aerobically from a single colony to an $\mathrm{OD}_{600}=0.3$ in Luria-Bertani (LB) medium supplemented with $100 \mu \mathrm{g} / \mathrm{mL}$ ampicillin at $37^{\circ} \mathrm{C}$. Untransformed DH10 $\beta$ cells were grown in LB without ampicillin. Protein expression was induced by the addition of $0.2 \%(\mathrm{w} / \mathrm{v}) L$-arabinose. Cells were harvested by centrifugation after $3 \mathrm{~h}$. Afterward, the cells were incubated with TMB $(200 \mu \mathrm{M})$ for $10 \mathrm{~min}$ and washed three times with PBS (pH 7.4).

\subsubsection{Escherichia coli Cells with the Exogenous PS MDPyTMPyP}

E. coli cells (ATCC 25922, Manassas, VA, USA) were grown aerobically from a single colony to an $\mathrm{OD}_{600}=0.3$ in LB medium at $37^{\circ} \mathrm{C}$. Then, cells were harvested by centrifugation and washed three times with PBS (pH 7.4). Afterward, cells were incubated with MDPyTMPyP $(10 \mu \mathrm{M})$, TMB $(200 \mu \mathrm{M})$, and $\mathrm{NaN}_{3}$ (if it was necessary; $50 \mathrm{mM}$ ) for $10 \mathrm{~min}$, followed by three washes with PBS (pH 7.4).

\section{Results}

\subsection{Photoacoustic and Spectroscopic Properties of TMB and Its Oxidation Products (2 and 3)}

The absorption spectra of TMB, the blue complex 2, and the yellow diimine 3 in PBS are shown in Figure 1A. TMB absorbs only in the ultraviolet region with a band centered at $290 \mathrm{~nm}$. Upon addition of $\mathrm{NaClO}$, we observed the formation of the blue complex 2, which absorbs throughout the visible spectrum with bands at 650,460 , and $370 \mathrm{~nm}$. When a light excess of $\mathrm{NaClO}$ relative to TMB was added, the blue complex 2 evolved to the yellow diimine 3 , which shows a single absorption band at $450 \mathrm{~nm}$. Further addition of $\mathrm{NaClO}$ oxidized 3 to uncolored products.
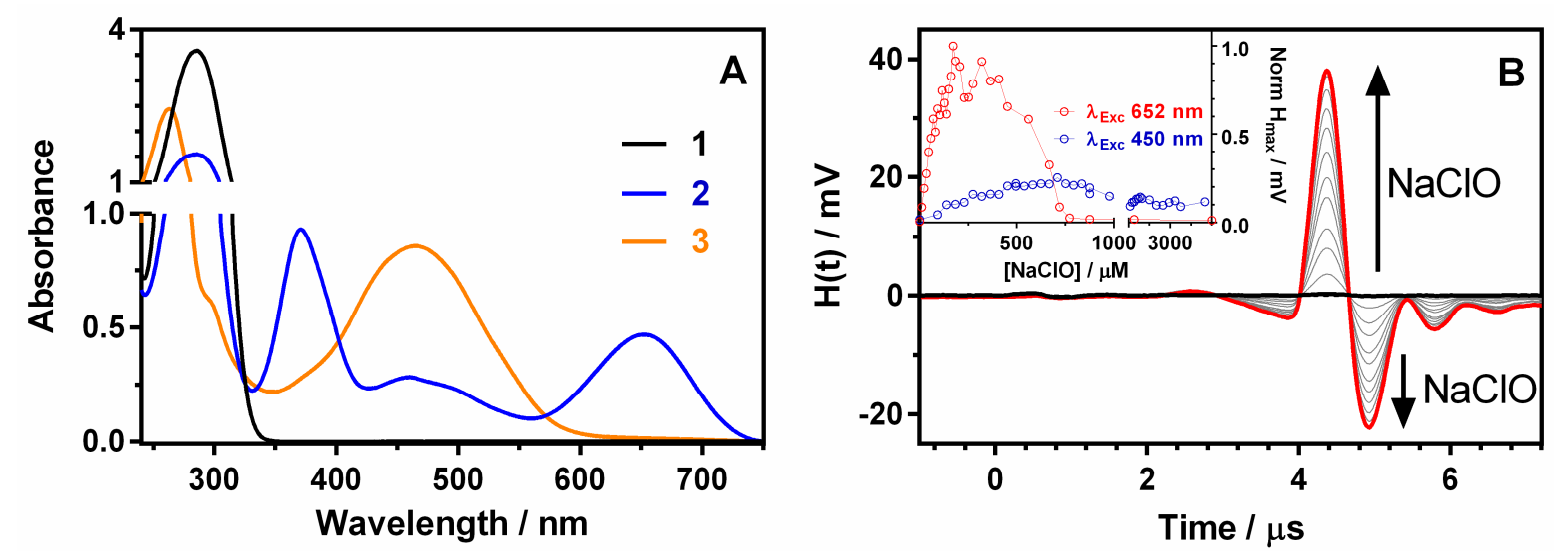

Figure 1. (A): Absorption spectra of TMB, 2 and 3, in PBS. (B): TMB photoacoustic waveforms enhancement upon successive $\mathrm{NaClO}$ additions in PBS $\left([\mathrm{TMB}]=200 \mu \mathrm{M} ;[\mathrm{NaClO}]=0-150 \mu \mathrm{M} ; \lambda_{\operatorname{exc}}\right.$ $=652 \mathrm{~nm}$ ). Inset: Photoacoustic maximum amplitude in function of the amount of $\mathrm{NaClO}$ added. The excitation wavelengths were 652 (2; red line) and 450 (3; blue line) $\mathrm{nm}$. [TMB] $=200 \mu \mathrm{M}$. 
Based on the absorption spectra of TMB, 2, and 3, we chose $652 \mathrm{~nm}$ for probing 2 and $450 \mathrm{~nm}$ for probing 3 in the photoacoustic experiments. A clear photoacoustic signal at $652 \mathrm{~nm}$ appeared upon the addition of $\mathrm{NaClO}$, which we ascribe to the formation of 2 (Figure 1B). The amplitude of the photoacoustic signal increased up to a maximum and then began to decrease, indicating the disappearance of 2 . Two factors contributed to this: as oxidation proceeds, there is less and less TMB available to form the complex 2 , resulting in the saturation of the signal at $\mathrm{NaClO}$ concentration $\sim 250 \mu \mathrm{M}$. Besides, $\mathrm{TMB}^{\bullet+}$ is further oxidized to the diamine 3 , which was demonstrated by the concomitant growth of the photoacoustic signal at $450 \mathrm{~nm}$ and its decrease at $652 \mathrm{~nm}$ at high $\mathrm{NaClO}$ concentration (Figure 1B inset).

\subsection{Factors Affecting the Photoacoustic Signal}

The amplitude of the photoacoustic signal reflects the amount of heat deposited in the system through radiationless decay of the excited states, as well as the differences in molecular volumes between the excited- and the ground-state species. Comparing the amplitude of the photoacoustic signal for $\mathbf{2}$ with that of the photocalorimetric reference BCP, the photoacoustic efficiency of 2 was determined as $\phi=0.95 \pm 0.10$ (Figure 2A). Kinetic analysis of the time-resolved photoacoustic signal revealed that the excited state decay of $\mathbf{2}$ is faster than the temporal resolution of the technique. Finally, $\mathbf{2}$ was found to be non-fluorescent. These results indicate that $\mathbf{2}$ is an ideal photoacoustic probe since it releases fast and efficiently as heat all the absorbed light energy. Additionally, the photoacoustic signal increases linearly with the excitation laser power (Figure S2) and is fairly photostable, since 8500 laser shots of $100 \mu \mathrm{J}$ are needed to reduce the signal by half (Figure S3), while to obtain a decent signal 10 shots of $10 \mu \mathrm{J}$ suffice.

Next, the effect of the TMB concentration was examined. The highest photoacoustic amplitude was observed when two equivalents of TMB reacted with one equivalent of $\mathrm{NaClO}$, therefore this proportion was kept for all experiments. A linear increase in the photoacoustic signal amplitude with TMB was observed up to roughly $30 \mu \mathrm{M}$ and the signal leveled off around $200 \mu \mathrm{M}$ (Figure S4) in agreement with Equation (1). Monitoring of 2 enables measurements of $\mathrm{NaClO}$ concentration up to $100 \mu \mathrm{M} . H_{\max }$ increases linearly with $\mathrm{NaClO}$ up to a concentration of $15 \mu \mathrm{M}$ (Figure $2 \mathrm{~B}$ ). The precision of the method has been assessed using 10 independent replicates obtaining a standard deviation of $15 \%$ (Figure S5), which is in line with typical standard deviation values for LIOAS. The detection and quantification limits have then been estimated as 0.6 and $1.4 \mu \mathrm{M}$, respectively (Figure S6).
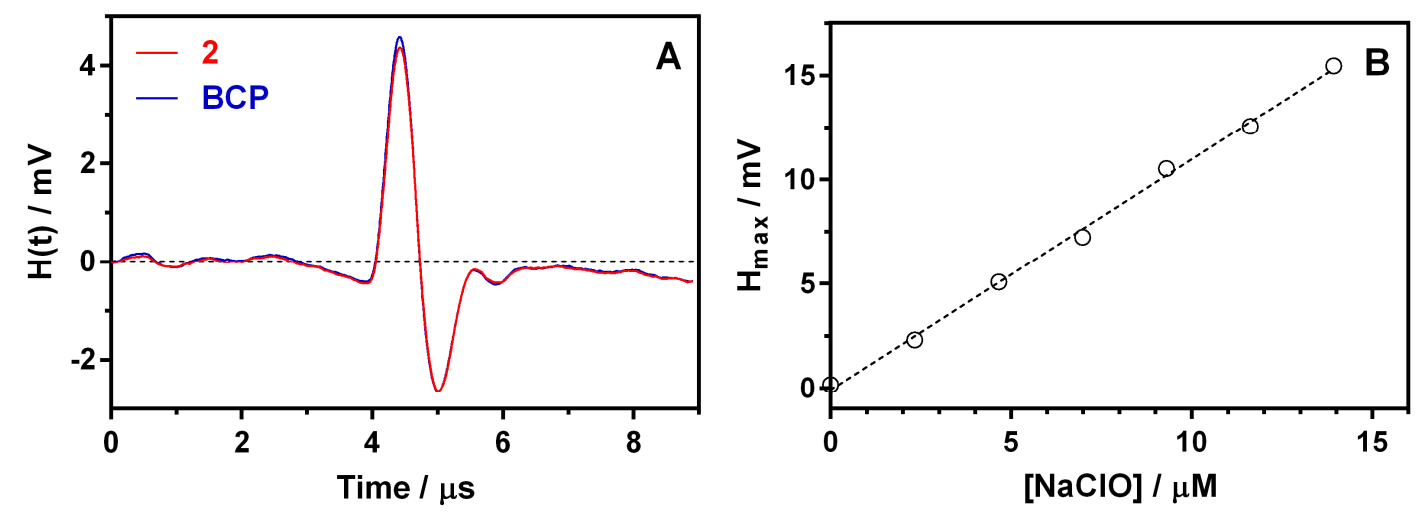

Figure 2. Determination of $\phi$ for 2 (red line) in PBS (pH 7.4). The reference photoacoustic wave was obtained using an optically matched bromocresol purple solution (BCP; $\phi=1(0.1 \mathrm{M} \mathrm{NaOH})$; blue line) [46] at the excitation wavelength $\left(\lambda_{\mathrm{Exc}}=652 \mathrm{~nm}\right)$. (B): Photoacoustic maximum amplitude vs. concentration of $\mathrm{NaClO}$ added in PBS (pH 7.4). [TMB] $=200 \mu \mathrm{M} ; \lambda_{\text {exc }}=652 \mathrm{~nm}$. 


\subsection{TMB Reactivity Towards the Tested ROS, RNS, and TEMPO}

After establishing the spectroscopic and photoacoustic properties of TMB, 2, and 3, we determined the reactivity of TMB towards other ROS, RNS, and the stable free radical TEMPO (Figure 3). Thus, TMB was allowed to react with them for $5 \mathrm{~min}$ before the photoacoustic response was recorded. For TEMPO and the stable ROS/RNS, we recorded the photoacoustic response at oxidant:TMB ratios ranging from 1:20 up to 10:1 eq, whereas for oxidants generated photochemically, we evaluated the photoacoustic response as a function of the irradiation time. When a species would not show any photoacoustic signal, we repeated the experiment in the presence of $100 \mu \mathrm{M} \mathrm{ClO}^{-}$as a control. The results are summarized in Scheme 2. Three types of response were observed:
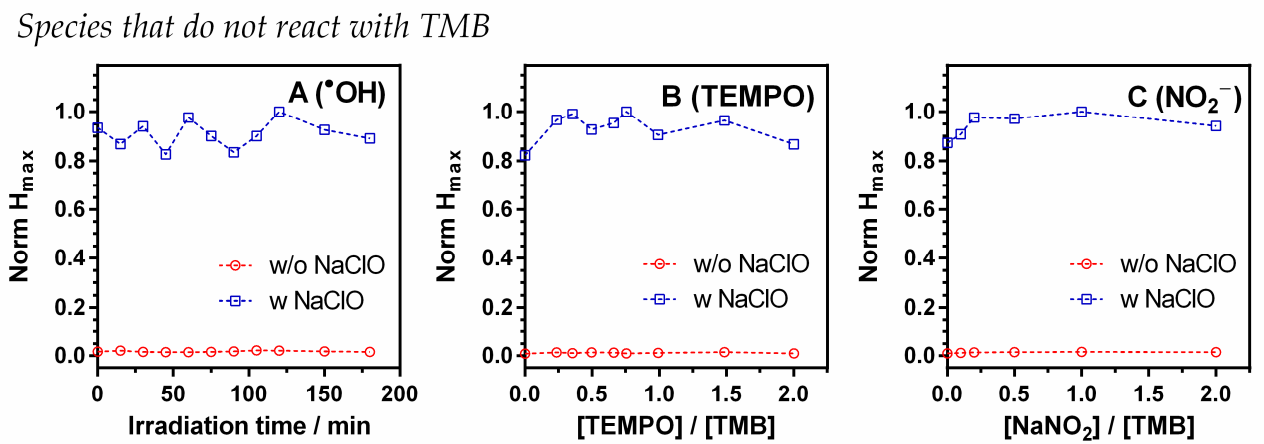

Species that react with TMB yielding 2
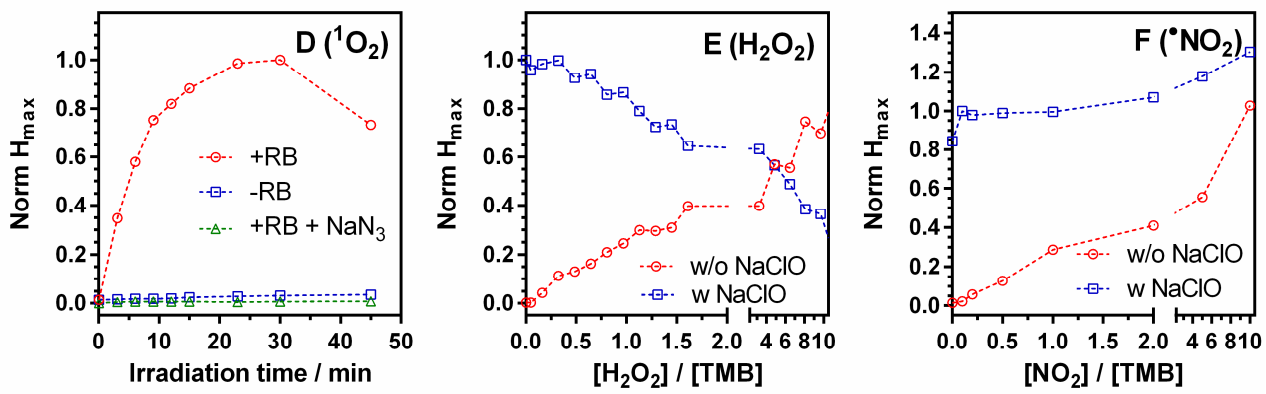

Species that react with TMB yielding other products
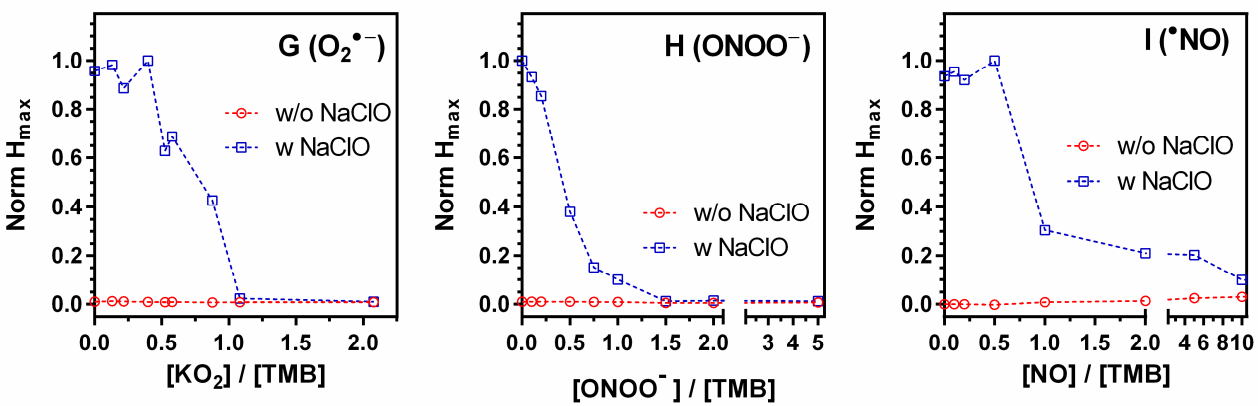

Figure 3. Photoacoustic maximum amplitude of TMB after reacting with different ROS and RNS. (A): Hydroxyl radical $\left(\bullet^{\bullet} \mathrm{OH}\right)$, generated via sodium nitrite photolysis in water $\left(\lambda_{\mathrm{exc}}=354 \pm 20 \mathrm{~nm}\right)$. (B): (2,2,6,6-Tetramethylpiperidin-1-yl)oxyl (TEMPO). (C): Sodium nitrite $\left(\mathrm{NaNO}_{2}\right)$. (D): Singlet oxygen $\left({ }^{1} \mathrm{O}_{2}\right)$, generated via Rose Bengal irradiation $\left(\lambda_{\mathrm{exc}}=520 \pm 18 \mathrm{~nm}\right)$. $\left(\right.$ E) : Hydrogen peroxide $\left(\mathrm{H}_{2} \mathrm{O}_{2}\right)$. $(\mathbf{F})$ : Nitrogen dioxide $\left({ }^{\bullet} \mathrm{NO}_{2}\right)$, generated via sodium nitrite acid decomposition. $(\mathrm{G})$ : Superoxide radical anion $\left(\mathrm{O}_{2}{ }^{\bullet-}\right)$. $(\mathbf{H})$ : Peroxynitrite $\left(\mathrm{ONOO}^{-}\right)$. $(\mathbf{I})$ : Nitric oxide $\left({ }^{\bullet} \mathrm{NO}\right)$, generated via sodium nitroprusside decomposition. As a control for B, C, E, F, G, H after the acquisition of the photoacoustic signal, $100 \mu \mathrm{M}$ $\mathrm{NaClO}$ was added and their photoacoustic signal was measured again (red and blue line, respectively). 


\subsubsection{Species That Give no Photoacoustic Signal}

This was the case for ${ }^{\bullet} \mathrm{OH}, \mathrm{TEMPO}$, and $\mathrm{NaNO}_{2}$ (Figure 3, panels A, B, C). TEMPO and $\mathrm{NaNO}_{2}$ did not react with TMB under these conditions. It is well known that nitrous acid $\mathrm{HNO}_{2}$ reacts with aromatic amines to form diazonium salts and leading eventually to the formation of colored diazo compounds. However, the $\mathrm{pK}_{\mathrm{a}}$ of $\mathrm{HNO}_{2}$ is 3.15 , therefore this reaction is not expected to occur at physiological $\mathrm{pH}$ [54]. The reduction potential of nitrite is $0.375 \mathrm{~V}$ vs. NHE [55], while the reduction

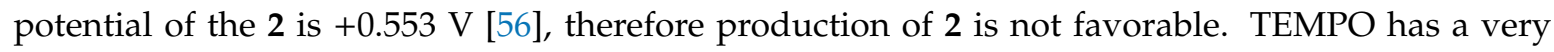
similar reduction potential $(+0.380 \mathrm{~V})$ [57], therefore no reaction is to be expected either. On the other hand, TEMPO may also react abstracting a hydrogen atom from TMB, however, the extent of this reaction seems to be negligible under our experimental conditions. Surprisingly, ${ }^{\bullet} \mathrm{OH}$ does not react with TMB despite having a most favorable reduction potential [58]. In general, $\bullet^{\bullet} \mathrm{OH}$ reactions tend to be diffusion-controlled owing to their strong reactivity. Indeed, ${ }^{\bullet} \mathrm{OH}$ reacts with TPA at the same concentration used for TMB $\left(200 \mu \mathrm{M}\right.$; Figure S1). As a final control, we added $100 \mu \mathrm{M} \mathrm{ClO}^{-}$to the analyzed solution and repeated the measurement. Reassuringly, the extent of production of $\mathbf{2}$ was the same in the absence and the presence of ${ }^{\bullet} \mathrm{OH}$. The same holds for TEMPO and $\mathrm{NaNO}_{2}$.

\subsubsection{Species That React with TMB Yielding 2}

In addition to $\mathrm{ClO}^{-}$(Figure 1), 2 was formed in the presence of $\mathrm{H}_{2} \mathrm{O}_{2}(+0.80 \mathrm{~V}),{ }^{1} \mathrm{O}_{2}(+0.81 \mathrm{~V})$, and $\cdot \mathrm{NO}_{2}(+1.04 \mathrm{~V})$, which have sufficiently high reduction potentials for oxidizing TMB (Figure 3, panels $\mathrm{D}, \mathrm{E}, \mathrm{F})[58$ ]. The photoacoustic signal increases in an almost linear fashion with the concentration of $\mathrm{H}_{2} \mathrm{O}_{2}$, although the maximum amplitude is not reached until an $\mathrm{H}_{2} \mathrm{O}_{2}$ :TMB ratio of about 15. This most likely indicates that the reaction with TMB is slow. Bearing in mind the prospective use of TMB for measurements in biological samples, we ruled out extending the time lag between TMB addition and measurement as well as the addition of accelerators such as horseradish peroxidase. The addition of $100 \mu \mathrm{M} \mathrm{ClO}^{-}$to the analyzed solutions produced a signal that decreased with the concentration of $\mathrm{H}_{2} \mathrm{O}_{2}$ in a complementary fashion to the increase observed in its absence. The sum of the signals before and after the addition of $\mathrm{ClO}^{-}$is approximately $100 \%$ in all cases. This indicates that $\mathrm{ClO}^{-}$ oxidizes the TMB that did not react $\mathrm{H}_{2} \mathrm{O}_{2}$, adding to the signal. Alternative reactions between $\mathrm{ClO}^{-}$ and $\mathrm{H}_{2} \mathrm{O}_{2}$, e.g., the production of ${ }^{1} \mathrm{O}_{2}$ [59] cannot be ruled out.

Figure 3D shows that ${ }^{1} \mathrm{O}_{2}$ reacts readily with TMB to produce the blue complex $2 .{ }^{1} \mathrm{O}_{2}$ is a metastable ROS that has a lifetime of $3.5 \mu \mathrm{s}$ in PBS. Therefore, it was generated in situ by irradiation of Rose Bengal (a well-known ${ }^{1} \mathrm{O}_{2}$ photosensitizer) with green light [50]. The amount of ${ }^{1} \mathrm{O}_{2}$ generated is proportional to the irradiation time. The photoacoustic signal shows a ${ }^{1} \mathrm{O}_{2}$ dependence very similar to that of $\mathrm{ClO}^{-}$, namely, a linear growth at short irradiation times (i.e., when the number of ${ }^{1} \mathrm{O}_{2}$ molecules generated is small, relative to that of TMB molecules), followed by saturation at longer times, corresponding to the maximum concentration of the complex 2 , and eventually to a steady signal decrease, indicating a shortage of reduced TMB molecules to sustain the complex 2 , as well as further oxidation of $\mathbf{2}$. When the experiment was repeated in the absence of RB or the presence of added $10 \mathrm{mM}$ sodium azide, a well-known ${ }^{1} \mathrm{O}_{2}$ scavenger [60], no photoacoustic signal could be observed beyond the base level. Thus, the formation of the blue complex 2 was indeed due to the reaction of TMB with photogenerated ${ }^{1} \mathrm{O}_{2}$.

The final oxidant in this group, ${ }^{\bullet} \mathrm{NO}_{2}$, shows a behavior very similar to that of $\mathrm{H}_{2} \mathrm{O}_{2}$ (Figure 3F). It reacts with TMB to yield the blue complex 2 and the reaction is not yet complete when the photoacoustic signal is recorded unless ${ }^{\bullet} \mathrm{NO}_{2}$ is added in 10 -fold excess. Unlike $\mathrm{H}_{2} \mathrm{O}_{2}$, the addition of $\mathrm{ClO}^{-}$gives the $100 \%$ signal system and even rises above this level at the highest ${ }^{\bullet} \mathrm{NO}_{2}$ concentrations, most likely due to light absorption by ${ }^{\bullet} \mathrm{NO}_{2}$ itself $\left(\sigma_{650}=1.54 \times 10^{-20} \mathrm{~cm}^{2} /\right.$ molecule; gas phase) [61]. 
a)

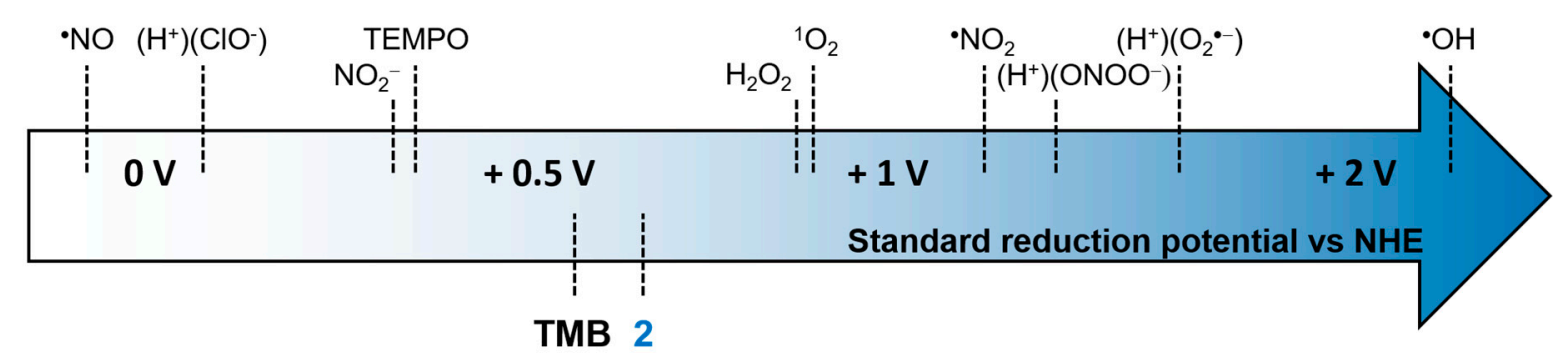

b)

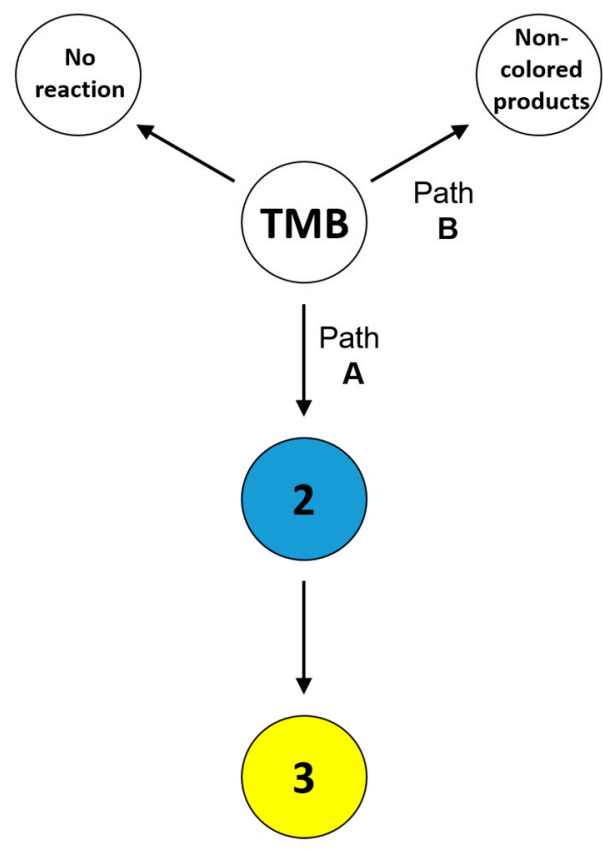

c)

\begin{tabular}{|c|c|c|c|}
\hline $\begin{array}{c}\text { ROS or } \\
\text { RNS }\end{array}$ & $\begin{array}{c}\text { No } \\
\text { Reaction }\end{array}$ & Path A & Path B \\
\hline$\cdot \mathrm{OH}$ & $\mathrm{x}$ & & \\
$\mathrm{TEMPO}$ & $\mathrm{x}$ & & \\
$\mathrm{NO}_{2}{ }^{-}$ & $\mathrm{x}$ & & \\
\hline $\mathrm{ClO}^{-}$ & & $\mathrm{x}$ & \\
$\mathrm{H}_{2} \mathrm{O}_{2}$ & & $\mathrm{x}$ & \\
${ }^{1} \mathrm{O}_{2}$ & & $\mathrm{x}$ & \\
$\cdot \mathrm{NO}_{2}$ & & $\mathrm{x}$ & \\
\hline $\mathrm{O}_{2}^{-}$ & & & $\mathrm{x}$ \\
$\mathrm{ONOO}-$ & & & $\mathrm{x}$ \\
$\cdot \mathrm{NO}$ & & & $\mathrm{x}$ \\
\hline
\end{tabular}

Scheme 2. (a) Standard reduction potentials for the different tested ROS, RNS, TEMPO, and TMB [55-58,62]. (b) The possible reaction pathways of TMB towards different ROS or RNS. (c) Table summarizing the reactivity towards TMB of the different ROS and RNS studied.

\subsubsection{Species That React with TMB Yielding Non-Colored Products}

This was the case of $\mathrm{O}_{2}{ }^{\bullet-}, \mathrm{ONOO}^{-}$and ${ }^{\bullet} \mathrm{NO}$, which did not form the blue charge-transfer complex 2 at any concentration or produced only minute amounts of it (Figure 3 panels G, H, I). As in the case of ${ }^{\bullet} \mathrm{OH}$, this was surprising because the reduction potentials are very favorable $\left(+1.46 \mathrm{~V}\right.$ for $\mathrm{O}_{2}{ }^{\bullet-}$ and $+1.20 \mathrm{~V}$ for $\mathrm{ONOO}^{-}$); less so for ${ }^{\bullet} \mathrm{NO},-0.15 \mathrm{~V}[58,62]$. Unlike the observations made for ${ }^{\bullet \bullet} \mathrm{OH}$, the subsequent addition of $\mathrm{NaClO}$ did not produce the $100 \%$ photoacoustic signal but a signal that decreased with the initially added concentration of the ROS/RNS as in the $\mathrm{H}_{2} \mathrm{O}_{2}$ case. This indicates that TMB had been consumed, however, yielded products different than 2 . Since our goal was to assess the usefulness of TMB as a photoacoustic probe for ROS/RNS, we did not seek to investigate the nature of such products. Nevertheless, a possible explanation for the strong oxidants $\mathrm{O}_{2}{ }^{\bullet-}$ and $\mathrm{ONOO}^{-}$is that $\mathrm{TMB}$ was oxidized to the diamine 3. Besides, it has been reported that $\mathrm{O}_{2}{ }^{\bullet-}$ can oxidize aniline (taken as a simple TMB model) to their correspondent nitro or nitroso derivatives [63] as well as to 4-nitro- $\mathrm{N}$-phenylaniline [64]. Similarly, $\mathrm{ONOO}^{-}$and ${ }^{\bullet} \mathrm{NO}$ can react with primary and secondary amines to yield $N$-nitrosamines and $N$-nitramines [65]. As a final note, it is worth noting, that for a high concentration of ${ }^{\bullet} \mathrm{NO}$ (20- and 30-eq.) a small amount of TMB is oxidized to yield $\mathbf{2}$, confirming the minor contribution of the electron-transfer reaction pathway. 


\subsection{Detection of ROS in Biological Media}

In the previous section, we established that TMB is a useful photoacoustic probe for $\mathrm{ClO}^{-}$and ${ }^{1} \mathrm{O}_{2}$ and, to a lesser extent, also for $\mathrm{H}_{2} \mathrm{O}_{2}$ and ${ }^{\bullet} \mathrm{NO}_{2}$. We then sought to assess its performance in biological media. To this end, we added TMB to suspensions of wt DH10 $\beta$ E. coli bacteria as well as three genetically modified strains that express the ROS photosensitizing proteins miniSOG and its mutants Q103V and Q103L, respectively. These are flavin-binding proteins that produce ${ }^{1} \mathrm{O}_{2}$ and other ROS in different proportions under exposure to blue light $(460 \mathrm{~nm})$ [66-68]. All strains produced a photoacoustic signal at $652 \mathrm{~nm}$, likely due to light absorption by heme. However, the signal was not enhanced upon exposure of the bacteria to blue light (Figure 4A and Figure S7). This indicates that no blue complex is formed, which may be due to TMB and the ROS being in distant cellular locations. Since the photosensitizing proteins are located in the cytoplasm, the most likely explanation is that TMB is not internalized by the bacteria.

To confirm this, we conducted a second experiment in which the ATCC 25922 E. coli cells were incubated with the porphyrin MDPyTMPyP (Scheme S3). We had previously demonstrated that the porphyrin MDPyTMPyP accumulates in the bacterial outer membrane and produces the characteristic ${ }^{1} \mathrm{O}_{2}$ emission at $1270 \mathrm{~nm}$ under exposure to light [69]. In this photoacoustic experiment, a clear enhancement was observed upon irradiation with $420 \mathrm{~nm}$ blue light, confirming the formation of the blue complex 2 (black line in Figure 4B and Figure S8). No enhancement was observed in the absence of MDPyTMPyP (blue line in Figure 4B). Next, we addressed the question of whether TMB binds to the bacteria or remains in the bulk solution. When we centrifuged the suspension and recorded the photoacoustic signal of the supernatant solution, no signal could be observed. However, we could recover it by resuspending the bacterial pellet (Figure S9). This indicates that TMB binds strongly to bacterial cells, but is not internalized by them. As a final experiment, we observed that the addition of $50 \mathrm{mM} \mathrm{NaN}_{3}$ (a selective ${ }^{1} \mathrm{O}_{2}$ scavenger) prevented the growth of the signal (red line in Figure 4B) [60]. Taken together, these experiments indicate that TMB can detect ${ }^{1} \mathrm{O}_{2}$ in biological media.
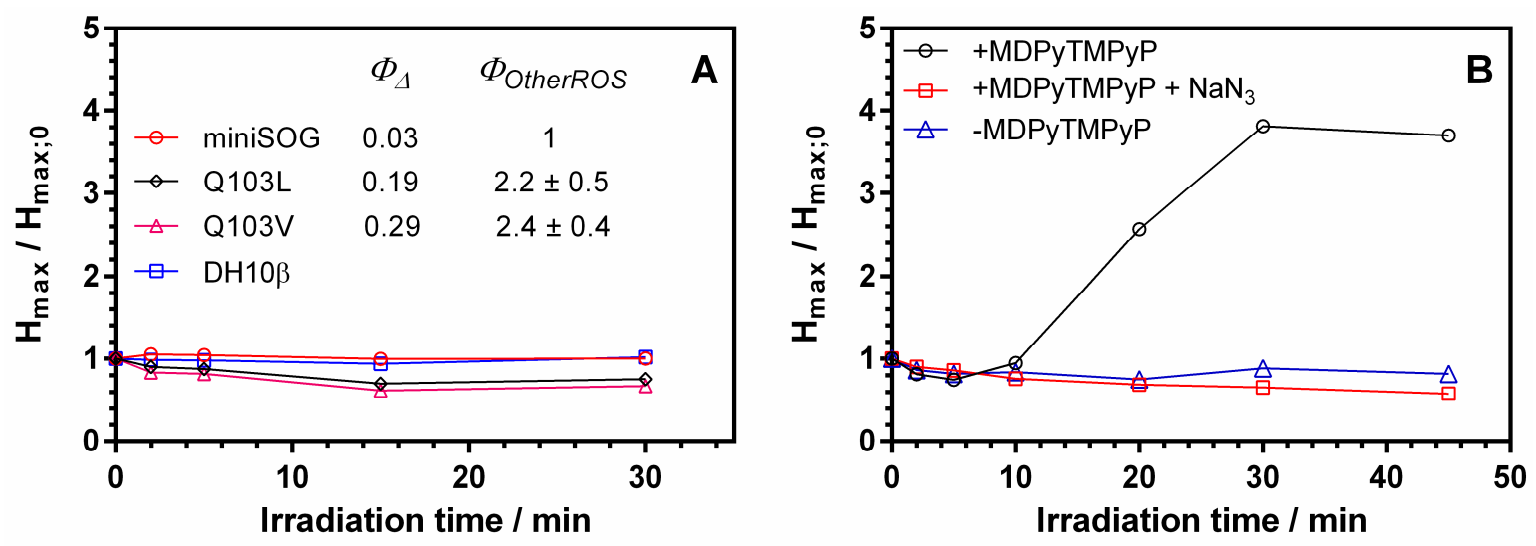

Figure 4. Photoacoustic maximum amplitude enhancement of TMB for (A) untransformed DH10 $\beta$ (blue squares) and miniSOG-expressing (red circles, black rhombuses, and magenta triangles for miniSOG, miniSOG Q103L and miniSOG Q103V, respectively) E. coli cells for different irradiation times (lamp power $14.0 \mathrm{~mW} / \mathrm{cm}^{2} ; \lambda_{\text {Irr }}=459 \pm 10 \mathrm{~nm}$ ). The values of ${ }^{1} \mathrm{O}_{2}$ quantum yield $\left(\Phi_{\Delta}\right)$ and relative generation of other ROS ( $\Phi_{\text {OtherROS }}$ ) by miniSOG and its mutants Q103L and Q103V are taken from [68]. (B): E. coli ATCC 25922 cells in the presence ( $200 \mu \mathrm{M}$; black circles) and absence (blue triangles) of MDPyTMPyP for different irradiation times (lamp power $5.5 \mathrm{~mW} / \mathrm{cm}^{2} ; \lambda_{\mathrm{Irr}}=420 \pm 20 \mathrm{~nm}$ ). The control experiment was realized coincubating MDPyTMPyP with $50 \mathrm{mM} \mathrm{NaN}_{3}$ (red squares).

Closer inspection of the time evolution of the photoacoustic signal reveals a time lag between the beginning of irradiation and the onset of the signal. This behavior has been observed also for fluorescent ROS probes in cells and is believed to reflect the scavenging of the first waves of ${ }^{1} \mathrm{O}_{2}$ by cellular antioxidants [70]. When these are consumed, TMB oxidation proceeds. 


\subsection{Discussion}

Photoacoustic imaging is based on the radiationless deactivation of photoexcited probes, a universal process. Photoacoustic probes have some advantages over fluorescent probes, such as the better transmission of sound in highly scattering biological media, and the possibility of tissue-depth profiling derived from the slower velocity of sound propagation [18]. In addition to these, acoustogenic probes offer the added advantage of, potentially, infinite contrast between the signals of the native and oxidized forms, derived from the color change [40]. This work shows that TMB is an acoustogenic photoacoustic probe that reacts with several ROS/RNS to yield a blue complex 2, which shows a photoacoustic signal with efficiency close to $100 \%$ when probed at $652 \mathrm{~nm}$. The main properties of TMB are summarized in Table 1.

Table 1. Main relevant properties of TMB (or their oxidation products).

\begin{tabular}{cc}
\hline Type of Probe & Acoustogenic \\
\hline$\lambda_{\max } / \mathrm{nm}$ & 652 \\
$\phi^{a}$ & $0.95 \pm 0.10$ \\
$\mathrm{LOD}^{b}\left(\mathrm{ClO}^{-}\right) / \mu \mathrm{M}$ & 0.6 \\
$\mathrm{LOQ}^{c}\left(\mathrm{ClO}^{-}\right) / \mu \mathrm{M}$ & 1.4 \\
$\operatorname{Responsivity}^{a}$ & $\mathrm{ClO}^{-},{ }^{1} \mathrm{O}_{2}, \mathrm{H}_{2} \mathrm{O}_{2}, \mathrm{NO}_{2}$ \\
\hline Photoacoustic efficiency. ${ }^{b}$ Limit of detection. ${ }^{c}$ Limit of quantification.
\end{tabular}

ROS/RNS probes can be classified as specific or non-specific. Selectivity is useful to pinpoint the role of a specific species in a chemical or biological process, as well as to quantify its concentration. However, in biological media, ROS interconvert very often through a complex network of pathways [1], therefore the use of specific probes is less critical. Non-specific probes such as $2^{\prime}, 7^{\prime}$-dichlorodihydrofluorescein are of widespread use in fluorescence microscopy as they provide useful information on overall oxidative stress [71]. We anticipate a similar role for $\mathrm{TMB}$, which does not detract from the interest in developing specific acoustogenic probes for particular ROS/RNS.

As a final comment, the ability to report the ROS level in biological media is an essential feature of probes, e.g., for dosimetry purposes in oxidation-based therapies such as photodynamic therapy [72,73]. Our work successfully demonstrates that TMB does not penetrate bacterial cells but is capable of detecting ${ }^{1} \mathrm{O}_{2}$ produced in the outer membrane of E. coli. There is little doubt that, as the photoacoustic imaging field will develop, other probes will be able to do this. Nevertheless, one of the most popular singlet oxygen fluorescent probes, Singlet Oxygen Sensor Green, is marketed as cell impermeant [74] and does not penetrate $E$. coli cells either [75].

\section{Conclusions}

Photoacoustic probes circumvent the main limitations of fluorescent probes, particularly tissue penetration and the need for transparent media. Besides, they can report in a depth-resolved manner taking advantage of the lower speed of propagation compared to light. We have demonstrated that the chromogenic TMB is a suitable photoacoustic probe for red-light monitoring of $\mathrm{ClO}^{-},{ }^{1} \mathrm{O}_{2}$, and, to a lesser extent, $\mathrm{H}_{2} \mathrm{O}_{2}$ and ${ }^{\bullet} \mathrm{NO}_{2}$ due to the formation of a blue complex upon oxidation. Other $\mathrm{ROS} / \mathrm{RNS}$ either do not react with TMB at any appreciable rate $\left({ }^{\bullet} \mathrm{OH}, \mathrm{NO}_{2}{ }^{-}\right.$, and the TEMPO radical) or yield photoacoustically silent products $\left(\mathrm{O}_{2}{ }^{\bullet}, \mathrm{ONOO}^{-}\right.$, and $\left.{ }^{\bullet} \mathrm{NO}\right)$. TMB binds to the outer membrane of the E. coli bacterial cell wall and aptly reports on ${ }^{1} \mathrm{O}_{2}$ located in its vicinity. The results of this work may pave the way to the development of new probes for photoacoustic imaging of a wide variety of biologically-relevant species, thereby providing a sensitive and selective alternative to fluorescence imaging.

Supplementary Materials: The following are available online at http://www.mdpi.com/1424-8220/20/20/5952/s1, Figure S1: Reactivity of terephthalic acid towards $\bullet$ OH. Figure S2: Laser energy dependence of photoacoustic maximum amplitude for 2. Figure S3: Photostability of 2 upon $652 \mathrm{~nm}$ laser-pulsed irradiation. Figure S4: Photoacoustic maximum amplitude for 2 as a function of the initial TMB concentration upon reaction with $\mathrm{ClO}^{-}$. 
Figure S5: Precision test. Figure S6: Limit of detection and limit of quantification test. Figure S7: Photoacoustic waveforms for different $E$. coli cell-suspension encoding different ROS generating proteins (miniSOG, miniSOG Q103L, miniSOG Q103V) as a function of the irradiation time. Figure S8: Photoacoustic waveforms for E. coli cell-suspension incubated with or without $10 \mu \mathrm{M}$ MDPyTMPyP as a function of the irradiation time. Figure S9: Photoacoustic waveforms for the supernatant and the pellet resuspension for E. coli cell-suspension incubated with $10 \mu \mathrm{M}$ MDPuTMPyP and irradiated for $45 \mathrm{~min}$. Scheme S1: Reactivity of terephthalic acid towards ${ }^{\bullet} \mathrm{OH}$. Scheme S2: Photolysis of $\mathrm{NaNO}_{2}$ in an aqueous environment to generate ${ }^{\bullet} \mathrm{OH}$. Scheme S3: Chemical structure of MDPyTMPyP.

Author Contributions: Conceptualization: R.B.-O. and S.N.; methodology: R.B.-O. and S,N.; Validation: R.B.-O. and S.N.; formal analysis: R.B.-O.; investigation: R.B.-O. and M.F.; resources: S.A., C.V., M.A., and S.N.; data curation: R.B.-O. and S.N.; writing-original draft preparation: R.B.-O. and S.N..; writing-review and editing: R.B.-O., M.F., S.A., C.V., M.A., and S.N.; visualization: R.B.-O. and S.N.; supervision: S.N..; project administration: S.N.; funding acquisition: S.N. All authors have read and agreed to the published version of the manuscript.

Funding: This research was funded by Ministerio de Economía y Competitividad (grant number CTQ2016-78454-C2-1-R), the European Social Funds and the SUR del DEC de la Generalitat de Catalunya (grant number 2017 FI_B2 00140) and the Vlaanderen Fonds Wetenschappelijk Onderzoek (grant number 12Z8120N). M.F. was recipient of an Erasmus+ traineeship.

Conflicts of Interest: The authors declare no conflict of interest.

\section{References}

1. Krumova, K.; Cosa, G. Overview of Reactive Oxygen Species. In Singlet Oxygen: Applications in Biosciences and Nanosciences, 1st ed.; Nonell, S., Flors, C., Eds.; RSC: London, UK, 2016; Volume 1, pp. 1-21.

2. Halliwell, B. Reactive species and antioxidants. Redox biology is a fundamental theme of aerobic life. Plant Physiol. 2006, 141, 312-322. [CrossRef] [PubMed]

3. Birben, E.; Sahiner, U.M.; Sackesen, C.; Erzurum, S.; Kalayci, O. Oxidative Stress and Antioxidant Defense. World Allergy Organ. J. 2012, 5, 9-19. [CrossRef] [PubMed]

4. Schieber, M.; Chandel, N.S. ROS Function in Redox Signaling and Oxidative Stress. Curr. Biol. 2014, 24, R453-R462. [CrossRef] [PubMed]

5. Patel, R.P.; McAndrew, J.; Sellak, H.; White, C.R.; Jo, H.; Freeman, B.A.; Darley-Usmar, V.M. Biological aspects of reactive nitrogen species. Biochim. Biophys. Acta 1999, 1411, 385-400. [CrossRef]

6. Corpas, F.J.; Barroso, J.B. Nitro-oxidative stress vs oxidative or nitrosative stress in higher plants. New Phytol. 2013, 199, 633-635. [CrossRef]

7. Foote, C.S. Definition of type I and type II photosensitized oxidation. Photochem. Photobiol. 1991, 54, 659. [CrossRef]

8. Agostinis, P.; Berg, K.; Cengel, K.A.; Foster, T.H.; Girotti, A.W.; Gollnick, S.O.; Hahn, S.M.; Hamblin, M.R.; Juzeniene, A.; Kessel, D.; et al. Photodynamic therapy of cancer: An update. CA. Cancer J. Clin. 2011, 61, 250-281. [CrossRef]

9. Wainwright, M.; Maisch, T.; Nonell, S.; Plaetzer, K.; Almeida, A.; Tegos, G.P.; Hamblin, M.R. Photoantimicrobials-Are we afraid of the light? Lancet Infect. Dis. 2017, 17, e49-e55. [CrossRef]

10. Winterbourn, C.C. Reconciling the chemistry and biology of reactive oxygen species. Nat. Chem. Biol. 2008, 4, 278-286. [CrossRef]

11. Jiménez-Banzo, A.; Ragàs, X.; Kapusta, P.; Nonell, S. Time-resolved methods in biophysics. 7. Photon counting vs. analog time-resolved singlet oxygen phosphorescence detection. Photochem. Photobiol. Sci. 2008, 7, 1003-1010. [CrossRef]

12. Yu, J.; Chen, J.; Li, C.; Wang, X.; Zhang, B.; Ding, H. ESR signal of superoxide radical anion adsorbed on $\mathrm{TiO}_{2}$ generated at room temperature. J. Phys. Chem. B 2004, 108, 2781-2783. [CrossRef]

13. Chen, X.; Wang, F.; Hyun, J.Y.; Wei, T.; Qiang, J.; Ren, X.; Shin, I.; Yoon, J. Recent progress in the development of fluorescent, luminescent and colorimetric probes for detection of reactive oxygen and nitrogen species. Chem. Soc. Rev. 2016, 45, 2976-3016. [CrossRef] [PubMed]

14. Nosaka, Y.; Nosaka, A.Y. Generation and detection of reactive oxygen species in photocatalysis. Chem. Rev. 2017, 117, 11302-11336. [CrossRef] [PubMed] 
15. Bresolí-Obach, R.; Torra, J.; Zanocco, R.P.; Zanocco, A.L.; Nonell, S. Singlet oxygen quantum yield determination using chemical acceptors. In Methods in Molecular Biology: Reactive oxygen species methods and protocols, 1st ed.; Espada, J., Ed.; Springer: Berlin/Heidelberg, Germany; Humana: New York, NY, USA, 2021; Volume 2202, pp. 165-188.

16. Sharma, S.K.; Hamblin, M.R. The use of fluorescent probes to detect ROS in photodynamic therapy. In Methods in Molecular Biology: Reactive Oxygen Species Methods and Protocols, 1st ed.; Espada, J., Ed.; Springer: Berlin/Heidelberg, Germany; Humana: New York, NY, USA, 2021; Volume 2202, pp. 215-229.

17. Dawson, J.B.; Barker, D.J.; Ellis, D.J.; Grassam, E.; Cotterill, J.A.; Fisher, G.W.; Feather, J.W. A theoretical and experimental study of light absorption and scattering by in vivo skin. Phys. Med. Biol. 1980, 25, 695-709. [CrossRef]

18. Ntziachristos, V.; Ripoll, J.; Wang, L.V.; Weissleder, R. Looking and listening to light: The evolution of whole-body photonic imaging. Nat. Biotechnol. 2005, 23, 313-320. [CrossRef]

19. Xu, M.; Wang, L.V. Photoacoustic imaging in biomedicine. Rev. Sci. Instrum. 2006, 77, 041101. [CrossRef]

20. Bell, A.G. On the production and reproduction of sound by light. Am. J. Sci. 1880, 3, 305-324. [CrossRef]

21. Braslavsky, S.E.; Heibel, G.E. Time-resolved photothermal and photoacoustic methods applied to photoinduced processes in solution. Chem. Rev. 1992, 92, 1381-1410. [CrossRef]

22. Gensch, T.; Viappiani, C. Time-resolved photothermal methods: Accessing time-resolved thermodynamics of photoinduced processes in chemistry and biology. Photochem. Photobiol. Sci. 2003, 2, 699-721. [CrossRef]

23. Miao, Q.; Pu, K. Emerging designs of activatable photoacoustic probes for molecular imaging. Bioconjug. Chem. 2016, 27, 2808-2823. [CrossRef]

24. Chen, Q.; Liu, X.; Chen, J.; Zeng, J.; Cheng, Z.; Liu, Z. A self-assembled albumin-based nanoprobe for in vivo ratiometric photoacoustic pH imaging. Adv. Mater. 2015, 27, 6820-6827. [CrossRef] [PubMed]

25. Weber, J.; Beard, P.C.; Bohndiek, S.E. Contrast agents for molecular photoacoustic imaging. Nat. Methods 2016, 13, 639-650. [CrossRef] [PubMed]

26. Knox, H.J.; Hedhli, J.; Kim, T.W.; Khalili, K.; Dobrucki, L.W.; Chan, J. A bioreducible N-oxide based probe for photoacoustic imaging of hypoxia. Nat. Commun. 2017, 8, 1794. [CrossRef]

27. Roberts, S.; Seeger, M.; Jiang, Y.; Mishra, A.; Sigmund, F.; Stelz, A.; Lauri, A.; Symvoulidis, P.; Rolbiesky, H.; Preller, M.; et al. Calcium sensor for photoacoustic imaging. J. Am. Chem. Soc. 2018, 140, 2718-2721. [CrossRef] [PubMed]

28. Ma, T.; Zheng, J.; Zhang, T.; Xing, D. Ratiometric photoacoustic nanoprobes for monitoring and imaging of hydrogen sulfide in vivo. Nanoscale 2018, 10, 13462-13470. [CrossRef] [PubMed]

29. Pu, K.; Shuhendler, A.J.; Jokerst, J.V.; Mei, J.; Gambhir, S.S.; Bao, Z.; Rao, J. Semiconducting polymer nanoparticles as photoacoustic molecular imaging probes in living mice. Nat. Nanotechnol. 2014, 9, $233-239$. [CrossRef]

30. Zhou, E.Y.; Knox, H.J.; Reinhardt, C.J.; Partipilo, G.; Nilges, M.J.; Chan, J. Near-infrared photoactivatable nitric oxide donors with integrated photoacoustic monitoring. J. Am. Chem. Soc. 2018, 140, 11686-11697. [CrossRef]

31. Yang, Z.; Dai, Y.; Yin, C.; Fan, Q.; Zhang, W.; Song, J.; Yu, G.; Tang, W.; Fan, W.; Yung, B.C.; et al. Activatable semiconducting theranostics: Simultaneous generation and ratiometric photoacoustic imaging of reactive oxygen species in vivo. Adv. Mater. 2018, 30, 1707509. [CrossRef]

32. Zheng, J.; Zeng, Q.; Zhang, R.; Xing, D.; Zhang, T. Dynamic-Reversible photoacoustic probe for continuous ratiometric sensing and imaging of redox status in vivo. J. Am. Chem. Soc. 2019, 141, 19226-19230. [CrossRef]

33. Hatamimoslehabadi, M.; Bellinger, S.; La, J.; Ahmad, E.; Frenette, M.; Yelleswarapu, C.; Rochford, J. Correlation of photophysical properties with the photoacoustic emission for a selection of established chromophores. J. Phys. Chem. C 2017, 121, 24168-24178. [CrossRef]

34. Boguta, A.; Wróbel, D. Fluorescein and phenolphthalein-Correlation of fluorescence and photoelectric properties. J. Fluoresc. 2001, 11, 129-137. [CrossRef]

35. Qi, J.; Li, J.; Liu, R.; Li, Q.; Zhang, H.; Lam, J.W.Y.; Kwok, R.T.K.; Liu, D.; Ding, D.; Tang, B.Z. Boosting fluorescence-photoacoustic-Raman properties in one fluorophore for precise cancer surgery. J. Chem. 2019, 5, 2657-2677. [CrossRef] 
36. Zhang, B.; Fang, C.Y.; Chang, C.C.; Peterson, R.; Maswadi, S.; Glickman, R.D.; Chang, H.C.; Yong-Ye, J. Photoacoustic emission from fluorescent nanodiamonds enhanced with gold nanoparticles. Biomed. Opt. Express 2012, 3, 1662-1669. [CrossRef] [PubMed]

37. Duffy, M.J.; Planas, O.; Faust, A.; Vogl, T.; Hermann, S.; Schäfers, M.; Nonell, S.; Strassert, C.A. Towards optimized naphthalocyanines as sonochromes for photoacoustic imaging in vivo. Photoacoustics 2018, 9, 49-61. [CrossRef] [PubMed]

38. Scaletti, F.; Truong, L.; Caplan, R.; Cao, A.; Bouchard, R.; Truskett, T.M.; Sokolov, K.V.; Johnston, K.P. Indocyanine green J aggregates in polymersomes for near-infrared photoacoustic imaging. ACS Appl. Mater. Interfaces 2019, 11, 46437-46450.

39. Frenette, M.; Hatamimoslehabadi, M.; Bellinger-Buckley, S.; Laoui, S.; La, J.; Bag, S.; Mallidi, S.; Hasan, T.; Bouma, B.; Yelleswarapu, C.; et al. Shining light on the dark side of imaging: Excited-state absorption enhancement of a bis-styryl BODIPY photoacoustic contrast agent. J. Am. Chem. Soc. 2014, 136, 15853-15856. [CrossRef] [PubMed]

40. Knox, H.J.; Chan, J. Acoustogenic probes: A new frontier in photoacoustic imaging. Acc. Chem. Res. 2018, 51, 2897-2905. [CrossRef] [PubMed]

41. Josephy, D.; Eling, T.; Mason, R. The horseradish peroxidase-catalyzed oxidation of 3,5,3',5'Tetramethylbenzidine. Free radical and charge-transfer complex intermediates. J. Biol. Chem. 1982, 257, 3669-3675.

42. Guo, Y.; Ma, Q.; Cao, F.; Zhao, Q.; Ji, X. Colorimetric detection of hypochlorite in tap water based on the oxidation of 3,3',5,5'-tetramethylbenzidine. Anal. Methods 2015, 7, 4055-4058. [CrossRef]

43. Zhang, X.; Huang, C.; Xu, S.; Chen, J.; Zeng, Y.; Wu, P.; Hou, X. Photocatalytic oxidation of TMB with the double-stranded DNA-SYBR Green I complex for label-free and universal colorimetric bioassay. Chem. Commun. 2015, 51, 14465-14468. [CrossRef]

44. Volpe, G.; Draisci, R.; Palleschi, G.; Compagnone, D. 3,3' ,5,5'-Tetramethylbenzidine as electrochemical substrate for horseradish peroxidase based enzyme immunoassays. A comparative study. Analyst 1998, 123, 1303-1307. [CrossRef]

45. Marquez, L.A.; Dunford, H.B. Mechanism of the oxidation of 3,5,3',5'-tetramethylbenzidine by myeloperoxidase determined by transient- and steady-state kinetics. Biochemistry 1997, 36, 9349-9355. [CrossRef]

46. Terazima, M.; Azumi, T. A time-resolved photoacoustic method with pulsed laser excitation in the condensed phase: The relation between signal intensity and decay-rate constant. Bull. Chem. Soc. Jpn. 1990, 63, 741-745. [CrossRef]

47. Abbruzzetti, S.; Viappiani, C.; Murgida, D.H.; Erra-Balsells, R.; Bilmes, G.M. Non-toxic, water-soluble photocalorimetric reference compounds for UV and visible excitation. Chem. Phys. Lett. 1999, 304, 167-172. [CrossRef]

48. Jankowski, J.J.; Kieber, D.J.; Mopper, K. Nitrate and Nitrite Ultraviolet Actinometers. Photochem. Photobiol. 1999, 70, 319-328. [CrossRef]

49. Barreto, J.C.; Smith, G.S.; Strobel, N.H.; McQuillin, P.A.; Miller, T.A. Terephthalic acid: A dosimeter for the detection of hydroxyl radicals in vitro. Life Sci. 1994, 56, PL89-PL96. [CrossRef]

50. Neckers, D.C. Rose Bengal. J. Photochem. Photobiol. A Chem. 1989, 47, 1-29. [CrossRef]

51. Soares, A.C.; Leite, R.; Tatsuo, M.A.; Duarte, I.D. Activation of ATP-sensitive $\mathrm{K}^{+}$channels: Mechanism of peripheral antinociceptive action of the nitric oxide donor, sodium nitroprusside. Eur. J. Pharmacol. 2000, 400, 67-71. [CrossRef]

52. Kim, M.; Ko, S.-K.; Kim, H.; Shin, I.; Tae, J. Rhodamine cyclic hydrazide as a fluorescent probe for the detection of hydroxyl radicals. Chem. Commun. 2013, 49, 7959-7961. [CrossRef]

53. Lin, L.; Xiao, D.; Yuan, H.; Choi, M.M.F.; Chan, W. A passive sampler for determination of nitrogen dioxide in ambient air. J. Chem. Educ. 2005, 82, 1231-1233. [CrossRef]

54. Mahouche-Chergui, S.; Gam-Derouich, S.; Mangeney, C.; Chehimi, M.M. Aryl diazonium salts: A new class of coupling agents for bonding polymers, biomacromolecules, and nanoparticles to surfaces. Chem. Soc. Rev. 2011, 40, 4143-4166. [CrossRef] [PubMed] 
55. Berks, B.C.; Ferguson, S.J.; Moir, J.W.B.; Richardson, D.J. Enzymes and associated electron transport systems that catalyze the respiratory reduction of nitrogen oxides and oxyanions. Biochim. Biophys. Acta 1995, 1232, 97-173. [CrossRef]

56. Cattaneo, M.V.; Luong, J.H.T. A water-soluble tetramethylbenzidine-2-hydroxypropyl- $\beta$-cyclodextrin inclusion complex as an efficient mediator for oxidoreductases. Electroanalysis 1996, 8, 223-228. [CrossRef]

57. Nutting, J.E.; Rafiee, M.; Stahl, S.S. Tetramethylpiperidine N-Oxyl (TEMPO), phthalimide N-oxyl (PINO), and related N-oxyl species: Electrochemical properties and their use in electrocatalytic reactions. Chem. Rev. 2018, 118, 4834-4885. [CrossRef]

58. Armstrong, D.A.; Huie, R.E.; Koppenol, W.H.; Lymar, S.V.; Merényi, G.; Neta, P.; Ruscic, B.; Stanbury, D.M.; Steenken, S.; Wardman, P. Standard electrode potentials involving radicals in aqueous solution: Inorganic radicals (IUPAC Technical Report). Pure Appl. Chem. 2015, 87, 1139-1150. [CrossRef]

59. Khan, A.U.; Kasha, M. Singlet molecular oxygen evolution upon simple acidification of aqueous hypochlorite: Application to studies on the deleterious health effects of chlorinated drinking water. Proc. Natl. Acad. Sci. USA 1994, 91, 12362-12364. [CrossRef]

60. Li, M.Y.; Cline, C.S.; Koker, E.B.; Carmichael, H.H.; Chignell, C.F.; Bilski, P. Quenching of singlet molecular oxygen $\left({ }^{1} \mathrm{O}_{2}\right)$ by azide anion in solvent mixtures. Photochem. Photobiol. 2001, 74, 760-764. [CrossRef]

61. Dixon, J.K. The absorption coefficient of nitrogen dioxide in the visible spectrum. J. Chem. Phys. 1940, 8, 157-160. [CrossRef]

62. Radi, R. Peroxynitrite, a stealthy biological oxidant. J. Biol. Chem. 2013, 288, 26464-26472. [CrossRef]

63. Frimer, A.A.; Aljadeff, G.; Ziv, J. Reaction of (arylmethyl)amines with superoxide anion radical in aprotic media. Insights into cytokinin senescence inhibition. J. Org. Chem. 1983, 48, 1700-1705. [CrossRef]

64. Stuehr, D.J.; Marietta, M.A. Superoxide-promoted oxidation reactions of aniline and N-methylaniline in dimethyl sulfoxide. J. Org. Chem. 1985, 50, 694-696. [CrossRef]

65. Masuda, M.; Mower, H.F.; Pignatelli, B.; Celan, I.; Friesen, M.D.; Nishino, H.; Ohshima, H. Formation of $\mathrm{N}$-nitrosamines and $\mathrm{N}$-nitramines by the reaction of secondary amines with peroxynitrite and other reactive nitrogen species: comparison with nitrotyrosine formation. Chem. Res. Toxicol. 2000, 13, 301-308. [CrossRef] [PubMed]

66. Shu, X.; Lev-Ram, V.; Deerinck, T.J.; Qi, Y.; Ramko, E.B.; Davidson, M.W.; Jin, Y.; Ellisman, M.H.; Tsien, R.Y. A genetically encoded tag for correlated light and electron microscopy of intact cells, tissues, and organisms. PLoS Biol. 2011, 9, e1001041. [CrossRef]

67. Ruiz-González, R.; Cortajarena, A.L.; Mejias, S.H.; Agut, M.; Nonell, S.; Flors, C. Singlet oxygen generation by the genetically encoded tag miniSOG. J. Am. Chem. Soc. 2013, 135, 9564-9567. [CrossRef] [PubMed]

68. Rodríguez-Pulido, A.; Cortajarena, A.L.; Torra, J.; Ruiz-González, R.; Nonell, S.; Flors, C. Assessing the potential of photosensitizing flavoproteins as tags for correlative microscopy. Chem. Commun. 2016, 52, 8405-8408. [CrossRef] [PubMed]

69. Ragàs, X.; Agut, M.; Nonell, S. Singlet oxygen in Escherichia coli: New insights for antimicrobial photodynamic therapy. Free Radic. Biol. Med. 2010, 49, 770-776. [CrossRef]

70. Bresolí-Obach, R.; Busto-Moner, L.; Muller, C.; Reina, M.; Nonell, S. NanoDCFH-DA: A silica-based nanostructured fluorogenic probe for the detection of reactive oxygen species. Photochem. Photobiol. 2018, 94, 1143-1150. [CrossRef] [PubMed]

71. Karlsson, M.; Kurz, T.; Brunk, U.T.; Nilsson, S.E.; Frennesson, C.I. What does the commonly used DCF test for oxidative stress really show? Biochem. J. 2010, 428, 183-190. [CrossRef]

72. Weston, M.; Patterson, M.S. Singlet oxygen dosimetry in biological media. In Singlet Oxygen: Applications in Biosciences and Nanosciences, 1st ed.; Nonell, S., Flors, C., Eds.; RSC: London, UK, 2016; Volume 2, pp. 151-168.

73. Pogue, B.W.; Elliott, J.T.; Kanick, S.C.; Davis, S.C.; Samkoe, K.S.; Maytin, E.V.; Pereira, S.P.; Hasan, T. Revisiting photodynamic therapy dosimetry: Reductionist \& surrogate approaches to facilitate clinical success. Phys. Med. Biol. 2016, 61, R57-R89. 
74. Singlet Oxygen Sensor Green Reagent Protoco. Available online: https://www.thermofisher.com/order/ catalog/product/S36002\#/S36002 (accessed on 11 October 2020).

75. Ruiz-González, R.; Bresolí-Obach, R.; Gulías, O.; Agut, M.; Savoie, H.; Boyle, R.W.; Nonell, S.; Giuntini, F. NanoSOSG: A nanostructured fluorescent probe for the detection of intracellular singlet oxygen. Angew. Chem. Int. Ed. 2017, 56, 2885-2888. [CrossRef]

Publisher's Note: MDPI stays neutral with regard to jurisdictional claims in published maps and institutional affiliations.

(C) 2020 by the authors. Licensee MDPI, Basel, Switzerland. This article is an open access article distributed under the terms and conditions of the Creative Commons Attribution (CC BY) license (http://creativecommons.org/licenses/by/4.0/). 